\title{
The Role of Law in Public Private Partnerships: Indonesia
}

\author{
Wahyu Kurniawan \\ Faculty of Law, Wijaya Putra University
}

\begin{abstract}
The Indonesian government have been accelerating infrastructures development. The objective is to fulfil the need for business sectors and to increase investments. The government use the Public Private Partnerships (PPPSs) model due to the limited financial resources derived from the State Budget (APBN). The PPPSs model, however, poses risks for the certainty of projects. The termination of projects would create the impact on subsequent plans related to the projects and also return of the investments and debts by investors and creditors. This article provides overview and argumentation of the legal devices that have been established by Indonesian Government to mitigate the risks of PPPSs projects based on the formal and substantive rules to be applied as standards for the object, subject, and of legal relationships in PPPSs.
\end{abstract}

Keywords: infrastructure; public private partnerships; risks; substantive law; formal law.

DOI: $10.7176 / \mathrm{JLPG} / 115-12$

Publication date: November $30^{\text {th }} 2021$

\section{Introduction}

The availability of infrastructure is conditio sine qua non for the community both to meet social and economic needs. For social life, infrastructure is useful to meet the needs and improve the mobility of the society. Infrastructure is also indispensable in economic activity to reduce investment and production costs.

The global economy will need $\$ 90$ trillion for infrastructure provision for 2016 to 2030 , which is allocated an average of \$ 5-6 trillion annually. ${ }^{1}$ Of the total investment required, developing countries in Asia will invest of $\$ 26$ trillion. $^{2}$ These funds are needed to maintain economic growth, eradicate poverty, and respond to climate change.

Indonesia is one of the countries in Asia that intensively build infrastructures. According to the National Development Planning Agency (Bappenas), the score of Indonesian infrastructures quality was only 4.2. This score was below the average of ASEAN countries, which are $4.4 .^{3}$ This proves that infrastructure is still an obstacle to national development. The implication of inadequate availability of infrastructures is increasing the transportation and logistics costs. These costs would be enormously if accumulated nationally and affect the competitiveness of national products at the international level.

In the National Mid-term Government Plan 2015-2019 (RPJMN) states the provisions of infrastructures are based on the equitable development as the objective of national development. ${ }^{4}$ The implementation of equitable development is constructing infrastructures nationally. Infrastructure provisions are for every region in Indonesia and not centralized on the Java Island. Furthermore, the purpose of this infrastructure's development is to connect between regions in Indonesia.

The state budget, however, has been insufficient to improve infrastructures to support the massive movement of the government policy in infrastructures. To overcome the limitations of these funds, the government provide an opportunity for the private sectors to be involved in the provisions of infrastructures. The government attract the private sectors to engage the provision of infrastructures with the Public Private Partnerships (PPPSs) scheme. This scheme has advantages for the state. The first advantage is the development and financing facilities carried out by the private sectors. Secondly, the private sector bears the risks incurred at the stage of construction and operation of infrastructure facilities. The government do not responsible for any losses incurred on the infrastructure provision.

However, PPPSs is not at all riskless. In the infrastructure development activities using PPPSs model is facing risks in three levels, which are macro, meso, and micro. The risks may occur in pre and post completion and result in termination of the development or operational of infrastructure facilities. This termination has direct impact on investors and creditors. In infrastructure development with this PPPSs model, private sectors finance $30 \%$ to $45 \%$ of the total projects. ${ }^{5}$ The projects are financing from the capital market, money market, or syndicated loans. In these circumstances, investors and creditors bear the risks to the certainty of project implementation. The impact would be even greater on the sustainability of development plans that depend on the

\footnotetext{
${ }^{1}$ Bhattacharya, Amar, Jeremy Oppenheim, dan Nicholas Stren (2015) Driving Sustainable Development Through Better Infrastructure: Key Elements of a Transformation Program, Global Economy and Development Working Paper 91, p. 8

${ }^{2}$ International Bank for Reconstruction and Development/The World Bank (2017) Mobilizing Islamic Finance For Infrastructure Public Private Partnerships, Report 2017, p. 10

${ }^{3}$ National Development Planning Agency (2017) Public Private Partnerships: Infrastructure Projects Plan in Indonesia, p. vi

${ }^{4}$ Rencana Pembangunan Jangka Menengah Nasional 2015-2019, point 6-85

${ }^{5}$ Supra note 3
} 
infrastructures are being built. As fundamentally understood that infrastructures development aim to provide the public interest to meet public needs and improve efficiency. The lack of infrastructures, territories and communities would not develop. Therefore, laws and regulations framework are required to manage these risks. These laws and regulations contain a substantive or formal legal order as standards for the implementation of PPPSs model projects.

This article will be divided into five sections. The first section describes the basic conception of PPPs. The second section presents the characteristics of PPPs to illustrate the differences with the procurement and privatization model. The third section explains the applicable PPPs laws and regulations in Indonesia. The fourth section clarifies the types of risks in PPPs. The fifth section explain the substantive law and formal law as a tool to mitigate the risks that will arise in the development and operationalization of PPPs projects through three aspects: planning and preparation aspect, procurement aspects of project business entity, and contracts to reduce uncertainty over the relationship between government and private in PPPs.

\section{The Concept of PPPs}

The basic concept of PPPs can be seen from the definitions of PPPs itself. This section shows the definitions from international organisations and followed by the definition based on applicable Indonesian law. These definitions will be elaborated to establish the scope and framework of the PPPS concept.

The first definition is from Organization for Economic Co-operation and Development (OECD). According to the OECD, PPPs is an agreement between the government and one or more private parties. In the agreement, the private sector provides services to gain profit in which the services are included in the objectives of government expectation to provide public utilities. The second definition is from the World Bank that states PPPs is a long-term contract between the government and the private sector in terms of building and/or managing facilities or services to public. ${ }^{1}$ The private sector bears risks and responsible for managing at all times as stipulated in the agreement. The private sector obtains the results of such management based on the implementation of management and/or demand or use of what it manages. The International Monetary Fund (IMF) defines the PPPs is an agreement whereby the private sector provides infrastructure in the form of assets and services traditionally carried out by the government. In the PPPs, the private sector is the party that provide and invest the infrastructure. This means that there is a transfer of the risks from the government to the private sector considering that both investment and infrastructure management are on the private sector.

The definition of PPPs contained in the Indonesia legislation is in Article 1 Point 6 of Presidential Regulation Number 38 of 2015 on Government Cooperation with Legal Entities in the Infrastructure Providing (hereinafter abbreviated as 'Presidential Regulation 38/2015'), which affirms that:

"Cooperation between the government and business entity in the provision of infrastructure for the public interest with reference to the pre-determined specification by the Minister/Head of Institution/Regional Head/State-Owned/Regional Owned Enterprise Entity, partly or wholly using the resources of the business entity with pay attention to risk sharing among the parties."

According to the definitions mentioned above, it can sort out the elements of PPPs. Firstly, the PPPs contains a long-term agreement between the government and the private sector. Based on the Presidential Regulation of PPPs, it is stipulated that the government are ministry, heads of institutions, regional heads, stateowned enterprises, or regional-owned enterprises. The private party wins the tender of the procurement phase forming a Special Purpose Vehicle (SPV). SPV is a company established specially in carrying out the project. SPV in Presidential Regulation of PPPs is also called PPPs Implementing Enterprise (PPPs-IE). PPPs-IE is a limited liability company ${ }^{2}$ established by a business entity that wins the tender or appointed directly to carry out the project.

Secondly, the private sectors undertake the development and management of facility. Private parties implement all activities from planning, construction, maintenance, and operation the facilities for the duration that has been agreed. Thirdly, there are transitions of risks from the government to the private sectors. With the implementation of planning until the operation of infrastructure, the risks are attached to the private party. The government does not bear any risks especially financial lost for the implementation of infrastructure development and operation.

Fourthly, private parties responsible to finance the construction and maintenance of the facilities. Projects financing may obtain from several sources, especially the capital market and banking. Fifthly, the private party gains benefit from asset operations. Private involvement in infrastructure is for profit-seeking purposes by build and manage public infrastructure. Sales and payment systems in PPPs are made through two systems: payment

\footnotetext{
${ }^{1}$ World Bank (2004) Public-Private Partnership Reference Guide Version 2.0, Washington

${ }^{2}$ Limited Liability Company is a business entity in the form of legal entity. The Law 40/2007 concerning Limited Liability Company governs this business entity. According to Article 1 Point 1 , limited liability company is a legal entity which is a capital alliance, established under an agreement, engages in business activities with a capital base wholly divided into shares and meets the requirements laid down in this Act and its implementing regulations.
} 
based on availability charge or user-by-charge usage charge. The scheme of payment system is based on the agreement between the government and the private sectors.

\section{Characteristics of PPPs}

The provisions of infrastructures are identified as a state action in providing public facilities. Traditionally, the government carries out this provision. The government, currently, do not dominate infrastructure development. The private sectors involve in the development and operationalization of facilities for the community.

This PPPs model is very different from the more dominant models so far such as the traditional procurement and privatization.

The differences between PPPs and the traditional procurement are as follows. The legal relationship between the government and the private sectors in traditional procurement is limited to the implementation of the design and construction of infrastructure that is governed by a design-build (DB) agreement. ${ }^{1}$ Private sectors build and the government finance and operate the infrastructure facilities. This is different from the PPPs model that private sectors carry out activities of Design-Build-Finance-Operate-Maintain (DBFOM) of facilities. The facilities will be returned to the government within a certain time frame as stipulated in the agreement.

PPPs also differs from privatization. Based on the Indonesian law, the concept of privatization is known as transfers of assets or equities from the state-owned enterprises (SoE) to the private sectors. ${ }^{2}$ The definition of privatization can be found in the Law No. 19 of 2003 concerning State Owned Enterprise (hereinafter abbreviated as 'Law of SoE'). In Article 1 Point 12 affirms that privatization as a result of the sale of shares of SoE either partially or wholly to the private party. The objective of privatization is to improve the performance or value of the company, increase benefits for the state and society, and share ownership to public.

Privatization as a transfer of assets is regulated in the Law No. 1/2004 concerning State Treasury and the Government Regulation No. 27 of 2014 concerning The Management of State/Local Property as the implementing regulation. This Government Regulation stipulates that the transfer of properties owned by state or regional government is classified privatization. The properties include the properties purchased or obtained at the expense of state or regional budgets and other legally obtained from grants or the like, properties obtained as execution of agreements, properties obtained in accordance with the provisions of statutory regulations, or properties obtained under a court decision which has permanent legal force. In the PPPs scheme, there is no action of transferring asset or equities from state to private sectors.

\section{Indonesian PPPs Laws}

The initial enactment of the Indonesian PPPs law was the Presidential Decree No. 7 of 1998 concerning PublicPrivate Partnerships in Development and/or Infrastructure Management (hereinafter referred to as 'Presidential Decree 7/1998') in 1998. The Presidential Decree 7/1998 was declared null and void by the enactment of the Presidential Regulation No. 67 of 2005 concerning Government Cooperation with Business Entities in the Provision of Infrastructure (hereinafter abbreviated as 'Presidential Regulation 67/2005'). This Presidential Regulation was substituted by Presidential Regulation No. 38 of 2015 concerning Government Cooperation with Business Entities in the Provision of Infrastructure (hereinafter abbreviated 'Presidential Regulation 38/2015').

Presidential Decree 7/1998 only regulated the development of economic infrastructures. The social infrastructures have not been regulated in the Presidential Decree until the enactment of Presidential Regulation 67/2005. Economic and social infrastructures remain as part of Presidential Regulation 38/2015.

Presidential Regulation 38/2015 affirms five objectives of the PPPs. ${ }^{3}$ Firstly, PPPs aim to provide for sustainable financing in the provision of infrastructure through the mobilization of private funds. Secondly, PPPs aims to realisation the provision of infrastructures with certain quality, effective, efficient, targeted, and timely. Thirdly, PPPs is endeavoured to encourage the participation of private sector in the provision of infrastructures based on sound business principles. Fourthly, PPPs encourages the use of the principle of users pay for services received, or in some cases consider the ability to pay users. Fifthly, PPPs provides certainty of return of investment of private sector in the provision of infrastructures through payment mechanism periodically by government to private sector.

The principles of PPPs adopted by the Presidential Regulation 38/2015 are as follows. ${ }^{4}$ Firstly, the principle of partnerships is the cooperation between the government and the private sector based on the legislation and considers the needs of both parties. Secondly, the principle of utilization is the provision of infrastructure by the government and private sector to provide social and economic benefits for the community. Thirdly, the fair competition principle is the procurement of business entity conducted through fair, open, and transparent.

\footnotetext{
${ }^{1}$ Grimsey, Darrin and Mervyn Lewis (2007) Public Private Partnerships and Public Procurement, Agenda, Volume 14, Number 2, pp. 171188

${ }^{2}$ Yescombe, E. R. (2007) Public-Private Partnership, Elsevier, Great Britain

${ }^{3}$ Article 3 the Presidential Regulation 38/2015

${ }^{4}$ Article 4 the Presidential Regulation 38/2015
} 
Fourthly, the principle of risk control and management states that the provision of infrastructure is based on risk assessment, development of management strategies, and risk mitigation. Fifthly, the effectiveness principle of cooperation provision of infrastructure is able to accelerate development while improving the quality of service management and maintenance of infrastructure. And the sixth principle is the efficiency principle that the cooperation of provision of infrastructure is sufficient for the sustainable funding needs and private sectors provide the financing of the provision of infrastructure.

\section{Risk in PPPs Projects}

Risks always exist in every provision of infrastructure facility. These risks cannot be avoided but managed and minimized in order to reduce any losses in the process of the development and operational of the infrastructures. The risks of PPPs projects are divided into two types of risks, which are risks based on levels and the risks that evolve during or after the construction phase.

Based on the level, the risks in projects are divided into three levels, which are macro, meso, and micro. ${ }^{1}$ Macro level risks are the external factors that can affect PPPs projects. These external factors can be political, state, legal, economic, social changes. The concrete forms of macro risk are unstable government, takeover or asset nationalization, poor public decision-making process, and strong political opposition. Natural factors are also categorized in macro-level risk. weather changes and natural disasters are risks that can occur and may affect the activities of PPPs projects.

Meso level risks are risks those arise within a PPPs project. The types of risks relate to the location, design, construction, and technology of the PPPs projects and the demand or use of the products of the projects. The concrete form of meso level risk is land acquisition, financial availability and investor appeal to the project, project approval and licensing delays, unrecovered engineering techniques, high construction costs, construction delays, availability of materials and labours, changes designs that cause delay, poor quality of work, bankruptcy or contractual failure of subcontractors or suppliers, high asset development or maintenance costs, low incomes, and other factors that may affect the implementation of PPPs projects.

Micro-level risks are same as meso, which are coming from within the projects. The difference is the meso risk associated with the project and the micro risk related to the relationship between the parties of the projects. These risks occur in the procurement process of business entity and interpretation of the agreement between the parties. These forms of risk are related to the organization and coordination between government and private parties, inadequate experience in projects, the distribution of responsibilities and their risks and insufficient authority, different methods of work and knowledge among parties, and the lack of commitment from both parties.

The risks of PPPs based on the phases are divided into two phases: pre-completion risk and post-completion risk. ${ }^{2}$ Pre-completion risk is a risk faced within the construction stage of infrastructure. While post-completion risk is a risk that may occur during the operational phase of infrastructure or after the development phase ends. Some risks also arise in both the pre-completion and post-completion stages.

The pre-completion risks include planning risk, technological risk, and construction risk. The risk of planning activities is the risk that occurs when infrastructure development is not in accordance with the planned schedule due to the availability of fund. Technology risk is changing of technology of construction a risk facing contractors. At the time of construction stage, contractor plan to use a certain technology agreed between the contractor and the business entity. Changes in conditions lead to a technological change in the process. The consequence is the delay in completion of infrastructure development. The construction risk is a postponement of the completion. This risk is due to several factors including, among others, the cost of a swollen construction, the delay of completion, the settlement resulting from performance inefficiency, and coercive conditions.

The main risks faced in the post-completion phase relate to the supply of raw materials, production risk, and market risk. Problems of raw materials can be less quantity or quality that affect the production. Another problem is the price of raw materials turns higher than previous estimation that affecting production costs. Change in production costs will affect the selling price of the product. Another risk in post-completion is production risk. This risk occurs when the function of facilities underperforms than the initial projections. It comes from discrepancy between planning and operations on facilities may lead to production inefficiency. Technically the asset that becomes the production tool has decreased performance. The result is that production is not optimal and affects output. The last risk is market risk. Market has changed due to the availability of other options of infrastructure.

In addition, there are also risks that appear in both pre-completion and post-completion. The types of risks that arise in both phases are the macro level risks of external factors that affect the development and operationalization of PPPs projects.

\footnotetext{
${ }^{1}$ Bing, Li, A. Akintoye, P.J. Edwards, dan C. Hardcastle (2005) The Allocation of Risk in PPPs/PFI Construction Projects in The UK, International Journal of Project Managemet 23, pp. 25-35

${ }^{2}$ Gatti, Stefano (2008) Project Finance in Theory and Practice, Elsevier, USA
} 


\section{Substantive and Formal Rules of PPPs Projects}

Infrastructure development deals with various forms of risks. These risks can be risks in major, meso, or minor classifications. Risk may also occur in the phase of pre completion and post completion. In this circumstance, law has a significant role to manage and reduce the risks.

Taylor argues that law is a tool for managing risk. The role of law is on substantive and formal rules. ${ }^{1}$ The role of substantive rule in managing risk of PPPs is as a standard to assess the subject, object, and legal relationship in PPPs based on scientific study. Science, however, has more than one assessment methods and the law must adopt one of these methods. ${ }^{2}$ The standard also determines the value of benefits of projects that are assessed in addition to the risks. ${ }^{3}$

The substantive rules are as a part of formal rules that the later govern the decision-making process. Formal rules govern the procedures to be performed when making policies. In PPPs, there are procedures implemented in several stages against the objects and subjects involved in PPPS and legal relations between the parties. Based on the formal Indonesian PPPs rules, there are three stages that must be fulfilled. These stages that must be taken in PPPs are: (i) planning and preparation PPPs projects; (ii) procurement of business entity; and (iii) contracts to ensure certainty between the government and the private sector in the PPPs. The implementation of these three stages, there are standards that are substantive and must be fulfilled. The purpose of implementing these steps is to produce an objective assessment of the objective PPPs project as well as the appropriate business entity.

\subsection{Planning and Preparation PPPs Projects}

The first phase of the PPPs process is the initial identification and feasibility carried out by the government. This stage is useful to know whether or not worthy of infrastructure development plan. The feasibility consists of investment financing feasibility, return on investment, and project development process.

The identification phase of infrastructure provision should consider five points. First, the projects are initiated in accordance with the national or regional development plan and the infrastructure sector strategic plan. Secondly, the projects should be in based on the spatial plan. Thirdly, infrastructure projects have linkages between infrastructure and inter-regional sectors. Fourthly, the project should be examined by benefit and social cost analysis. Fifthly, the infrastructure to be built should be reviewed by value for money analysis.

Five considerations mentioned above, the first to third aspects are based on the national and regional policies on infrastructure development. The fourth and fifth aspects are more focused on micro risk approach directly related to infrastructure projects. The purpose of objective study with scientific methodology is to identify the benefit, social influence, and value for money of the project

This aspect of benefit and social is carried out with the benefit-cost analysis (BCA) method. BCA predicts the feasibility of the project based on the comparison between the benefits to the community and the costs to be expanded by the community. In contrast to the analysis of value for money (VfM) with a more quantitative method leads to the financial aspect. The purpose of this study is to estimate the overall financial impact of the project, consideration of operating costs and risk costs, and net present value (NPV).

The result of the initial feasibility resulted in seven standards. The seven standards are stipulated in Article 30 Paragraph (2) Presidential Regulation 38/2015 namely: (i) source of financing; (ii) identification of contractual, regulatory and institutional frameworks; (iii) technical design; (iv) proposals of support and government guarantees; (v) identification of risks and mitigation recommendations, and the allocation of risks; and (vii) the return on investment of the executing agency.

\subsection{Procurement of Business Entity}

The stage of procurement of business entities in PPPs for infrastructure is regulated in the Regulation of the Head of Government Procurement Policy Agency Number 19 of 2015 concerning Procedures for the Implementation of State-Owned Enterprises in Cooperation with Business Entities in the Provision of Infrastructure (hereinafter referred to as 'GPPA 19/2015'). The procurement of business entities carries out by the procurement committee established by the government. This committee has a role and responsibility to prepare and implement the procurement process to select the business entity.

The steps undertaken by the Executing Committee is divided into two namely the preparation and implementation. In this preparation stage, the procurement committee conducted five important activities. First, the procurement committee must confirm the readiness of the PPPs project by reviewing the completeness of the

\footnotetext{
${ }^{1}$ Taylor, Michael R. (1984) The Role of Law in Risk Management: A Framework for Managing Uncertainty, Fundamental and Applied Toxicology 4, pp.408-417, p. 410

Taylor states four variables to lessen the risks which are substantive rules for decision making, procedural rules, activities aimed at enforcing substantive rules, and judicial involvement in the decision making process. This article, however, uses substantive and formal rules as variables to identify the PPPS laws that mitigate the risks in PPPS projects.

2 ibid. p. 411

3 ibid
} 
document or the readiness of the PPPs project to proceed to the procurement phase. Second, the procurement committee confirms the interest of the market to identify the certainty of the interest of the market to the project by reviewing the market sounding results that have been done before by the government or conducting a discussion in the forum business entity. Thirdly, the procurement committee prepares the schedule for the procurement of the business entity and the draft announcement. Fourthly, the procurement committee prepares and stipulates the procurement documents of the business entity consisting of the Prequalification Document and Proposal Request Document. Lastly, the procurement committee manages the data and information space for the purposes of due diligence. Participants who pass the prequalification and have submitted a confidentiality letter are granted access to data rooms containing documents related to PPPs projects, procurement documents, and copies of documents relating to the procurement of business entity distributed to participants.

The second stage is the procurement process of the PPPs business entity. This stage is divided into two phases, which are prequalification, and election. The prequalification includes prequalification announcement activities, registration and taking of prequalification documents, explanation of PPPs projects, scope of activities of PPPs project implementers and prequalification documentation, prequalification participants including qualification documents, qualification evaluation, stipulation and announcement of qualification results and qualification rebuttal. Prequalification participants will be assessed on administrative requirements, technical skills, and financial capabilities. If a business entity passes prequalification more than one then the procurement stage is executed by auction. If only one participant who passes the assessment will be followed by direct appointment.

Auction of election of PPPs business entity is classified in two forms: one-stage auction and two-stage auction. The differences between the two auction forms are as follows. One-stage auctions when: (i) specifications of infrastructure provision can be clearly defined; or (ii) does not require discussion of technical optimization in order to achieve optimal output. Unlike the two-stage auction which: (i) the specification of the provision of infrastructure cannot be formulated with certainty because there are variations of innovation and technology; and (ii) require the optimization of technical bidding in order to achieve optimal output.

Direct appointments may also be made if the PPPs is for a particular condition or there is only one participant who passes the prequalification stage. The criteria of certain conditions underlying the direct appointment are: (i) the development of infrastructure already built and/or operated by the same business entity; (ii) work that can only be carried out with the use of new technologies and service providers capable of applying the sole; or (iii) the business entity has controlled most or all of the land required for the implementation of the PPPs.

\subsection{PPPs Contract}

Every PPPs is required to make a cooperation agreement between the government and the private sector. As regulated in Article 32 Paragraph (1) of Presidential Regulation 38/2015, the government has an obligation to prepare cooperation agreement draft. Article 32 Paragraph (2) mentions the minimum standards of clauses in the cooperation agreement.

In addition, in Indonesian law also regulates clauses contained in the contract particularly relating to assets, rights and obligations that arise in relation to assets, namely: (i) the purpose of asset utilization and the prohibition to utilize assets for purposes other than which has been agreed upon; (ii) operational and maintenance responsibilities, including payments of taxes and other liabilities arising from the use of assets; (iii) the rights and obligations of the party who controls the asset to supervise and maintain the asset's performance during its use; (iv) a prohibition for the business entity to pledge assets as collateral to the third parties; (v) the procedure for the delivery and/or return of assets; and (vi) other matters in accordance with the provisions of legislation.

The cooperation agreement also governs matters relating to assets. The clauses governing the assets are: (i) the condition of the assets to be transferred; (ii) asset transfer procedures; (iii) asset status is not as collateral; (iv) asset status free from third party claims; and (v) the exemption of the government from any claims arising after the transfer of the assets.

In the circumstance that the project uses Intellectual Property Rights (IPR) then this shall also be stipulated in the agreement. There are three things that must be regulated in connection with intellectual property rights. First, the intellectual property used is completely free from all forms of lawlessness. Secondly, the government shall be exempt from any claim from any third party relating to the use of IPR in the provision of infrastructure. Thirdly, the provision of infrastructure can still be implemented and the use of IPR may continue despite the claim or demand for IPR.

Referring to international best practice and statutory provisions applicable in Indonesia, the characteristics of PPPs agreement is general. The substance of the agreement is made general and avoids the rigid nature and does not set specific and technical provisions. This occurs because the PPPs cooperation agreement is a longterm agreement. Characteristic of long-term agreement is cannot be made in detail. 
The performance of agreement will deal with unforeseen circumstances and changes that will affect the implementation of the agreement itself. Therefore, the agreement will be made incomplete which is different from the complete contract in which the parties specify in detail the rights and obligations attached to each party.

This long-term agreement will deal with changing circumstances, especially external conditions that affect the implementation of the contract. ${ }^{1}$ Therefore, contracts on PPPs need to be made to anticipate future conditions that cannot be predicted. Although made in general but the agreement does not lose the analytical content of rights and obligations. The analytical aspect that becomes a tool to ensure legal certainty in the PPPs cooperation agreement is framed in a commitment that contains the achievements that must be performed.

The consequences of the character inherent in the PPPs cooperation agreement as an incomplete contract is used as theoretical approach in the design and performance of the agreement. In the science of contract law, the theory of promise dominates the frame of mind in creating and analysing a covenant. This theory, however, is not suitable to be the foundation on long-term contracts due to the simplification the meaning of the agreement itself. Promise theory has disadvantage and inappropriate to be applied to PPPs contracts due to the reason that promise is a simplification of a complex legal relationship. ${ }^{2}$ Cooperation agreement on PPPs does not regulate specific and predictable legal relationships. Macro, meso, and micro risks may occur and affect the performance of the contract.

Therefore, the PPPs cooperation agreement is more appropriate using the theory of exchange relationship theory. Based on this theory, the performance of contract is constructed at aspects of the relationship between the government and the private sector and not merely rights and obligations that must be implemented rigidly. Exchange relationship is defined broadly including the willing and things those are not regulated but become part of the commitment and the willing of the parties in the frame of the purposes contained in the contract.

\section{Conclusion}

PPPs is an infrastructure development scheme involving the private sector. The objective is to meet the needs of public facilities but to the extent of insufficient funding problems from the state budget.

Risks would arise during the provision of infrastructure facilities. Law becomes a tool to mitigate such risks. Formal and substantive laws serve as appropriate mechanisms for reducing risk. Indonesian PPPs laws have been regulated comprehensively to provide certainty and predictability for the provision of infrastructure through PPPs mechanisms.

The formal law regulates that the provision of infrastructure must follow through three stages from project planning and preparation, selection of business entities through procurement processes, and legal arrangements between government and the private sector in the agreement. In the formal process, there are substantive aspects that must be implemented to obtain objective results. Assessment objectivity is inherent in project planning and preparation based on scientific studies, transparent and fair selection of business entity, and flexible legal arrangements to adapt to changes at the operational stage of infrastructure facilities.

\section{References}

Bhattacharya, Amar, Jeremy Oppenheim, and Nicholas Stren (2015) Driving Sustainable Development Through Better Infrastructure: Key Elements of a Transformation Program, Global Economy and Development Working Paper 91

Bing, Li, A. Akintoye, P. J. Edwards, dan C. Hardcastle (2005) The Allocation of Risk in PPPS/PFI Construction Projects in The UK, International Journal of Project Managemet 23, pp. 25-35

Gatti, Stefano (2008) Project Finance in Theory and Practice, Elsevier, USA

Grimsey, Darrin and Mervyn Lewis (2007) Public Private Partnerships and Public Procurement, Agenda, Volume 14, Number 2, pp. 171-188

De Geest, Gerrit (ed.) (2000) Encyclopedia of Law and Economics Vol. III, Elgar, Washington

Hviid, Morten (2000) Long-Term Contracts and Relational Contracts, in Gerrit De Geest (ed.), Encyclopedia of Law and Economics Vol. III, Elgar, Washington

International Bank for Reconstruction and Development/The World Bank (2017) Mobilizing Islamic Finance For Infrastructure Public Private Partnerships, Report 2017

Lightsey, Wallace K. (1984) A Critique of the Promise Model of Contract, William and Mary Law Review Vol. $26: 45$

Taylor, Michael R., (1984) The Role of Law in Risk Management: A Framework for Managing Uncertainty, Fundamental and Applied Toxicology 4, pp.408-417

National Development Planning Agency (2017) Public Private Partnerships: Infrastructure Projects Plan in Indonesia

${ }^{1}$ Hviid, Morten (2000) Long-Term Contracts and Relational Contracts, in Gerrit De Geest (ed.), Encyclopedia of Law and Economics Vol. III, Elgar, Washington

${ }^{2}$ Wallace K. Lightsey, A Critique of the Promise Model of Contract, William and Mary Law Review Vol. 26:45, 1984 
Rencana Pembangunan Jangka Menengah Nasional 2015-2019

World Bank (2004) Public-Private Partnership Reference Guide Version 2.0, Washington

Yescombe, E. R. (2007) Public-Private Partnership, Elsevier, Great Britain 